\title{
PENGARUH BAHAN BAKU, KEWIRAUSAHAAN DAN PENGALAMAN KERJA TERHADAP PRODUKSI DAN PENDAPATAN INDUSTRI KULINER RUMAH MAKAN
}

\author{
I Made Andre Prana Cita ${ }^{1}$ \\ Ni Luh Karmini ${ }^{2}$ \\ ${ }^{1,2}$ Fakultas Ekonomi dan Bisnis Universitas Udayana (Unud), Bali, Indonesia \\ Email:andrecokoll@gmail.com/ Telp.085739454520
}

\begin{abstract}
ABSTRAK
Berkembang pesatnya industri kuliner rumah makan saat ini menjadi peluang bagi generasi muda untuk dapat membuka bisnis kuliner serta dapat memadukan inovasi kekinian untuk menarik konsumen. Penelitian ini bertujuan untuk mengatahui dan menganalisis pengaruh bahan baku, kewirausahaan dan pengalaman kerja terhadap produksi dan pendapatan industri kuliner rumah makan di Kota Denpasar. Data dalam penelitian ini adalah data primer dengan kuesioner.Populasi dalam penelitian adalah seluruh pelaku usaha rumah makan.Sampel yang digunakan sebanyak 76 dengan Simple Random Sampling.Teknik analisis jalur digunakan. Hasil penelitian menunjukkan bahwa bahan baku dan kewirausahaan berpengaruh positif dan signifikan terhadap produksi industri, pengalaman kerja tidak berpengaruh terhadap produksi industri. Bahan baku, kewirausahaan, dan produksi berpengaruh positif dan signifikan terhadap pendapatan, pengalaman kerja tidak berpengaruh terhadap pendapatan. Bahan baku dan kewirausahaan berpengaruh secara tidak langsung terhadap pendapatan melalui produksi, pengalaman kerja tidak berpengaruh secara tidak langsung terhadap pendapatan melalui produksi industri kuliner rumah makan.
\end{abstract}

Kata kunci :Bahan Baku, Kewirausahaan, Pengalaman Kerja, Produksi, Pendapatan.

\begin{abstract}
The rapid development of the restaurant is currently an opportunity for the younger generation to be able to open culinary business and can combine innovations to attract consumers. This study aims to find out the influence of raw materials, entrepreneurship and work experience on the production and income of the culinary industry in Denpasar. The population in the study were all restaurant businesses. The sample used was 76 with Simple Random Sampling. Path analysis techniques are used. The results of the study show that raw materials and entrepreneurship have positive and significant effect on industrial production, work experience has no effect on industrial production. Raw materials, entrepreneurship, and production have positive and significant effect on income, work experience has no effect on income. Raw materials and entrepreneurship have indirect effect on income through production, work experience does not have indirect effect on income through the production of the restaurant's industry.
\end{abstract}

Keywords:Raw Materials, Entrepreneurship, Work Experience, Production, Income. 


\section{PENDAHULUAN}

Pembangunan merupakan suatu proses perubahan menuju arah yang lebih baik dan terus menerus untuk mencapai tujuan yakni mewujudkan masyarakat yang berkeadilan, berdaya saing maju dan sejahtera. Indonesia sebagai negara berkembang dalam upaya pembangunannya masih perlu menata dan medorong segala sektor yang dimiliki guna mampu mencapai tujuan pembangunan yang diinginkan, dari kesemua sektor yang ada salah satu sektor yang berperan besar dalam pembangunan di Indonesia adalah sektor industry (Kuyvenhoven, 2006)Menurut Mulyadi \& Hartono (2018)menyatakan bahwa pemerintah terus mendorong sektor industri untuk dapat bersaing secara global. Hal ini mengingat perannya yang amat penting sebagai leading sector dalam mendorong pertumbuhan ekonomi nasional. Suatu perekonomian dikatakan mengalami pertumbuhan apabila jumlah produksi barang dan jasa yang dihasilkan secara umum meningkat (Ningsih \& Indrajaya, 2015)

Industri kuliner pada dasarnya merupakan industri yang menawarkan cita rasa selera makanan dan minuman dengan berbagai bentuk olahan yang menarik minat konsumen(Lumpkin \& Dess, 1996). Keberadaan industri kuliner khususnya rumah makan yang ada di Kota Denpasar merupakan tempat-tempat kuliner yang dapat dengan mudah dijangkau oleh semua kalangan masyarakat baik dari segi ekonomi, pilihan cita rasa yang enak, serta produk-produk kuliner yang ditawarkan dapat memanjakan selera konsumen.

Perkembangan rumah makan setiap tahunnya mengalami fluktuasi begitu juga pada jumlah tenaga kerja yang digunakan.Tahun 2013 jumlah industri 
kuliner rumah makan di Kota Denpasar berjumlah 383 usaha dengan jumlah tenaga kerja sebesar 4.250 orang, kemudian perkembangannya mengalami fluktuasi tiap tahun, hingga di tahun 2017 keberadaan jumlah industri kuliner rumah makan di Kota Denpasar berjumlah 385 dengan tenaga kerja yang dimiliki 4.172 orang.

Tabel 1.

Jumlah Rumah Makan dan Tenaga Kerja Industri Kuliner Rumah Makan di Kota Denpasar, 2013-2017.

\begin{tabular}{ccc}
\hline Tahun & Jumlah Usaha & Tenaga Kerja \\
\hline 2013 & 383 & 4.250 \\
2014 & 368 & 4.103 \\
2015 & 376 & 4.103 \\
2016 & 376 & 4.105 \\
2017 & 385 & 4.172 \\
\hline
\end{tabular}

Sumber :Data Diolah, 2018.

Berfluktuasinya keberadaan industri kuliner rumah makan di Kota Denpasar secara umum di lapangan dapat dipengaruhi oleh beberapa faktor seperti kondisi ekonomi, yaitu kurang stabilnya keadaan ekonomi wilayah yang berpengaruh terhadap menurunnya daya beli masyarakat, banyaknya pesaing yang mampu lebih unggul dari segi inovasi produk, dan kurang menyasarnya produk yang dihasilkan terhadap kalangan generasi milenial atau selera kuliner masyarakat, sehingga diperlukannya upaya-upaya yang lebih kreatif dan inovatif dalam menyasar keberadaan konsumen. Hal tersebut juga di dukung oleh penelitian Sancoko(2015)yang menyatakan bahwa berkembangnya industri kuliner dapat dipengaruhi oleh faktor internal dan eksternal usaha. Dari internal usaha berkembangnya industri kuliner harus didukung oleh sumber daya pekerja, sedangkan dari eksternal usaha di dipengaruhi oleh kondisi ekonomi, sosial, politik, dan lingkungan sekitar. 
Eksistensi dari keberadaan industri kuliner di suatu wilayah yaitu dapat diketahui dari sisi pendapatan yang diperoleh oleh pengusaha, karena pendapatan yang menjadi faktor penentu bertahan dan berkembangnya usaha yang dijalankan. Pendapatan merupakan keseluruhan dana yang diperoleh dari menjalankan kegiatan usaha dan menjadi cerminan kemajuan ekonomi suatu masyarakat.

Semakin baik pendapatan yang diterima oleh pelaku industri kuliner maka semakin baik pula perkembangannya di masyarakat dan dapat berkontribusi bagi pemerintah daerah melalui pajak yang dibayarkannya dan berbagai bentuk sumbangan sosial yang diberikan untuk pembangunan dan kemajuan wilayah.(Suartha, 2016).Selain itu industri kuliner yang semakin berkembang dimasyarakat memungkinakan semakin baik pula keberadaannya dalam penyediaan kesempatan kerja bagi masyarakat sekitar, dapat memberikan multiplier effect terhadap kemajuan ekonomi wilayah bersangkutan, seperti pembelian bahan baku serta dapat mendukung keberadaan usaha-usaha kecil lainnya.(Wiyasa. \& Dewi, 2017)

Salah satu faktor yang menentukan besarnya pendapatan yang diperoleh oleh pelaku usaha adalah dari banyaknya output yang dihasilkan dari kegiatan produksi. Produksi merupakan proses dalam mengolah, menghasilkan, menciptakan nilai tambah/nilai guna suatu barang atau jasa yang dihasilkan. (Moissevea, 2009).Sebagai upaya dalam mendukung produksi yang maksimal diperlukannya alokasi penggunaan input produksi seperti bahan baku yang berkualitas dan dapat dipergunakan secara efektif dan efisien dalam menghasilkan output yang optimal.(Widnyana., Budhi, \& Saskara, 2017) 
Bahan baku pada sektor kuliner umumnya jarang dapat bertahan lama, hal ini dikarenakan olahan pangan baik berupa daging maupun sayuran pada dasarnya cenderunglebih cepat mengalami proses pembusukan yang pada akhirnya mempengaruhi proses produksi(Wiagustini dkk.,2017) Faktor ini apabila diabaikan maka akan berpengaruh terhadap pendapatan industri kuliner rumah rumah makan, sehingga diperlukan pemahaman dari pemilik industri untuk bisa mengatur penggunaan bahan baku dalam proses produksi (Covin \& Slevin, 1989). Penjelasan ini sejalan dengan penelitian Suartawan \&Purbadharmaja (2017)yang mengatakan tersedianya bahan baku dalam perusahaan merupakan suatu hal penting untuk dikendalikan di suatu perusahaan, yang nantinya dengan pengendalian tersebut dapat memberikan pendapatan yang optimal.

Selain penggunaan bahan baku faktor berikutnya sebagai penentu lainnya adalah jiwa kewirausahaan yang menjadi hal penting bagi pengusaha secara umum. (Oforoi, 2006).Keberanian mengambil resiko dan memiliki inovasi serta proaktif terhadap usaha yang dijalankan adalah indikator bahwa seorang pengusaha mempunyai mental kewirausahaan yang kreatif dan inovatif dalam menjalankan bisnisnya.(Cannice, Allen, \& Tarrazo, 2016)

Selain faktor penggunaan bahan baku dan kewirausahaan, terdapat faktor lain yang memiliki peranan penting dalam perkembangan industri kuliner yaitu pengalaman kerja pengusaha dalam menjalankan aktivitas usahanya. Pengalaman kerja adalah faktor yang sangat berpengaruh dalam menciptakan pertumbuhan suatu usaha (Muliani \& Suresmiathi, 2015). Adanya pengalaman kerja yang dimiliki oleh pemilik industri kuliner akan menentukan kualitas dalam kinerja 
industri yang dijalankan. Pengalaman yang didapat sangat mempengaruhi tingkah laku orang tersebut dalam mengambil keputusan kedepan dan itu dianggap sebagai kesempatan dalam membenah diri dan menciptakan usaha kearah yang lebih maju.(Lyon, Lumpkin, \& Dess, 2000)

Berdasarkan latar belakang yang telah dipaparkan, maka dapat diidentifikasi rumusan masalah adalah 1) Bagaimana pengaruh langsung penggunaan bahan baku, kewirausahaan dan pengalaman kerja terhadap jumlah produksi industri kuliner rumah makan di Kota Denpasar? 2) Bagaimana pengaruh langsung penggunaan bahan baku, kewirausahaan, pengalaman kerja dan produksi terhadap pendapatan industri kuliner di Kota Denpasar? 3) Adakah pengaruh tidak langsung penggunaan bahan baku, kewirausahaan dan pengalaman kerja terhadap pendapatan melalui produksi industri kuliner rumah makan di Kota Denpasar?

Kerangka konseptual dalam penelitian ini disajikan dalam Gambar 1 sebagai berikut.

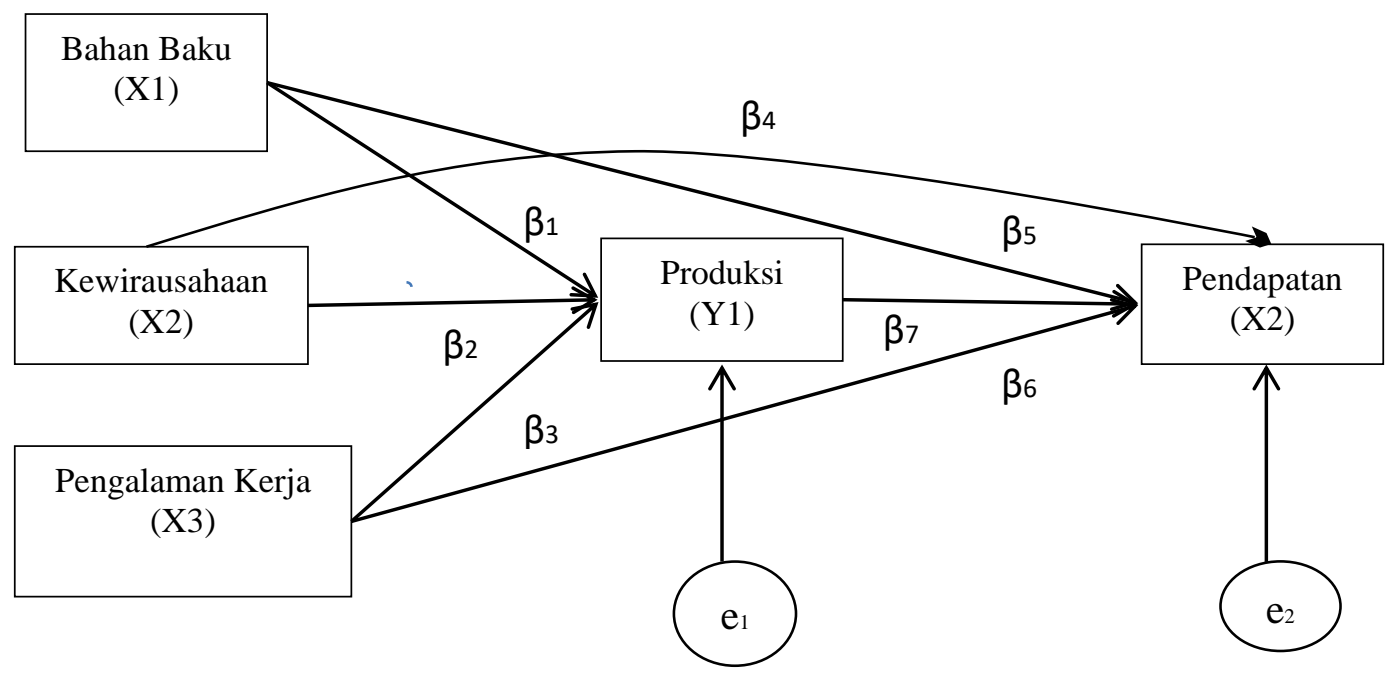

Gambar 1. Kerangka Konseptual Pengaruh Bahan baku, Kewirausahaan dan Pengalaman Kerja terhadap Produksi dan Pendapatan Industri Kuliner Rumah Makan di Kota Denpasar 
Berdasarkan rumusan masalah dan kajian pustaka maka dapat disusun hipotesis penelitian sebagai berikut: 1) Penggunaan bahan baku, kewirausahaan dan pengalaman kerja berpengaruh langsungterhadap produksi industri kuliner rumah makan di Kota Denpasar. 2) Penggunaan bahan baku, kewirausahaan, pengalaman kerja dan produksi berpengaruh langsung terhadap pendapatan industri kuliner rumah makan di Kota Denpasar 3) Terdapat pengaruh tidak langsung penggunaan bahan baku, kewirausahaan, pengalaman kerja terhadap pendapatan melalui produksi industri kuliner rumah makan di Kota Denpasar.

\section{METODE PENELITIAN}

Penelitian ini menggunakan pendekatan kuantitatif yang berbentuk asosiatif.Lokasi penelitian ini berada di Kota Denpasar, dipilih lokasi ini didasari karena Kota Denpasar merupakan barometer perekonomian di Bali yang juga memiliki jumlah penduduk yang padat dengan selera yang cepat berubah, sehingga memberikan peluang bagi berkembangnya sektor industri kuliner utamanya industri kuliner rumah makan di Kota Denpasar. Disamping itu Kota Denpasar yang terkenal dengan sektor pariwisata, dapat juga dijadikan peluang bagi berkembangnya industri kuliner dalam menunjang aktivitas wisatawan.

Objek penelitian ini memfokuskan kepada pengaruh bahan baku, kewirausahaan dan pengalaman kerja terhadap produksi dan pendapatan industri kuliner kategori rumah makan yang tersebar di empat kecamatan di Kota Denpasar.Variabel terikat (dependent variable) dalam penelitian ini adalah produksi $\left(\mathrm{Y}_{1}\right)$ dan pendapatan $\left(\mathrm{Y}_{2}\right)$ industri kuliner rumah makan di Kota 
Denpasar.Variabel bebas dalam penelitian ini adalah jumlah bahan baku $\left(\mathrm{X}_{1}\right)$, kewirausahaan $\left(\mathrm{X}_{2}\right)$ dan pengalaman kerja $\left(\mathrm{X}_{3}\right)$.Dalam penelitian ini yang menjadi variabel intervening adalah produksi $\left(\mathrm{Y}_{1}\right)$.

Definisi Operasional Variabel, bahan baku $\left(\mathrm{X}_{1}\right)$ merupakan input/faktorfaktor produksi yang dipergunakan dalam menunjang kegiatan produksi atau menghasilkan output. Bahan baku yang digunakan dalam penelitian ini yaitu jumlah pengeluaran untuk pembelian bahan baku yang diperlukan oleh pelaku usaha kuliner dalam melaksanakan proses produksi selama periode satu bulan terakhir, yang akan diukur dengan skala rasio dalam satuan rupiah.

Kewirausahaan $\left(\mathrm{X}_{2}\right)$ merupakan tindakan atau kemampuan inovatif di dalam menjalankan usaha.Yang dimaksud inovatif pada penelitian ini adalah berinovasi dalam menghidangkan produk olahan atau tampilan menu makanan, melakukan promosi online (pemasaran digital) dan menciptakan pengalaman berkunjung/pelayanan seperti tersedianya fasilitas wifi untuk konsumen pada industri kuliner rumah makan. Kewirausahaan akan diukur dengan menggunakan variabel dummy, yaitu $\mathrm{D}=1$ jika pelaku usaha kuliner rumah makan telah menerapkan prinsip kewirausahaan yang inovatif dalam menjalankan usaha. Sedangkan $\mathrm{D}=0$ jika pelaku usaha kuliner rumah makan tidak menerapkan prinsip kewirausahaan yang inovatif dalam menjalankan usaha.

Pengalaman kerja $\left(\mathrm{X}_{3}\right)$ merupakan pengalaman yang dimiliki dan telah diterapkan oleh pemilik industri kuliner rumah makan dalam menjalankan usahanya. Pada penelitian ini pengalaman kerja yang akan diteliti yaitu seberapa 
lama pengalaman yang dimiliki oleh pelaku usaha dalam menjalankan usaha yang akan diukur dalam skala rasio dan dinyatakan dalam satuan tahun.

Produksi ( $\left.\mathrm{Y}_{1}\right)$ adalah nilai/jumlah dari keseluruhan barang dan jasa yang merupakan hasil akhir dari proses produksi pada suatu unit usaha yang selanjutnyaakan dijual kepada konsumen. Dalam penelitian ini produksi industri kuliner akan diukur dengan menggunakan skala rasio dalam satuan porsi, yaitu dari banyaknya penjualan per porsi makanan yang laku terjual selama satu bulan.

Pendapatan ( $\left.\mathrm{Y}_{2}\right)$ adalah hasil berupa uang atau materi lainnya yang diperoleh dari kegiatan penjualan industri kuliner rumah makan di Kota Denpasar. Pendapatan dalam penelitian ini akan diukur dengan skala rasio, yaitu dari besarnya jumlah pendapatan yang di diperoleh oleh pelaku usaha selama satu bulan yang dinyatakan dalam satuan rupiah.

Teknik penentuan sampel dalam penelitian ini yaitu dengan menggunakan teknik probability sampling dengan metode simple random sampling.Populasi dalam penelitian ini adalah keseluruhan industri kuliner rumah makan yang ada di Kota Denpasar.Jumlah sampel pelaku usaha industri kuliner rumah makan yang dijadikan sampel dalam penelitian ini adalah sebanyak 79 responden yang tersebar di Kota Denpasar.Jenis data yang digunakan dalam penelitian ini, terdiri dari data kuantitatif dan kualitatif.Data Primer dalam penelitian ini adalah data-data yang didapat melalui penyebaran kuisioner dan melakukan wawancara mendalam dengan narasumber yang bersangkutan.Data sekunder dalam penelitian ini adalah data-data yang di dapatkan di Badan Pusat Statitik, Dinas Pariwisata Kota Denpasar. 
Dalam memperoleh data yang diperlukan, penelitian ini menggunakan beberapa teknik pengumpulan data sepertiObservasi non prilaku, Wawancara terstruktur dan Wawancara mendalam

\section{HASIL DAN PEMBAHASAN}

Jumlah penduduk Kota Denpasar terus mengalami peningkatan, pada tahun 2013 jumlah penduduk Kota Denpasar yaitu sebesar 846,2 ribu orang. Hingga pada tahun 2017 jumlah penduduk di Kota Denpasar mengalami perubahan peningkatan menjadi 914,3 ribu orang. Dibandingkan laju pertumbuhan penduduknya, laju pertumbuhan penduduk di Kota Denpasar mengalami penurunan yaitu sebesar 2,09 persen di tahun 2013 dan menjadi 1,89 persen pada tahun 2017. Dengan rata-rata laju pertumbuhan penduduk pada tahun 2013-2017 yaitu sebesar 1,56 persen. Peningkatan jumlah penduduk yang ada pada dasarnya disebabkan urbanisasi dan migrasi tinggi yang dilakukan oleh penduduk ke Kota Denpasar.

Tabel 2.

Jumlah dan Laju Pertumbuhan Penduduk Kota Denpasar Tahun 2013-2017

\begin{tabular}{ccc}
\hline Tahun & $\begin{array}{c}\text { Jumlah Penduduk } \\
\text { (Ribu Orang) }\end{array}$ & $\begin{array}{c}\text { Laju Pertumbuhan } \\
\text { (Persen) }\end{array}$ \\
\hline 2013 & 846,2 & 2.09 \\
2014 & 863,6 & 2,06 \\
2015 & 880,6 & 1,97 \\
2016 & 897,3 & 1,90 \\
2017 & 914,3 & 1,89 \\
\hline
\end{tabular}

Sumber :Data Diolah, 2018.

Adapun data jumlah persebaran penduduk di masing-masing Kecamatan Kota Denpasar tahun 2017 adalah penduduk terbesar adalah Kecamatan Denpasar 
Selatan dengan jumlah penduduk sebesar 292.670 jiwa atau 32,01 persen dari total penduduk Kota Denpasar. Kemudian di ikuti oleh Kecamatan Denpasar Barat 264.490 jiwa atau 28,93 persen, Kecamatan Denpasar Utara 201.380 jiwa atau 22,03 persen dan Kecamatan Denpasar Timur 155.760 jiwa atau sebesar 17,04 persen.

Tingginya jumlah penduduk di Kota Denpasar dapat memicu terjadinya penurunan tingkat kesempatan kerja dan berimplikasi terhadap pengangguran, tingkat kemiskinan, timbulnya perkampungan kumuh serta mampu memicu turunnya tingkat kesejahteraan dan menjadi beban dalam pembangunan wilayah.Peristiwa ini bisa terjadi jika pemerintah tidak sigap untuk menyediakan lapangan pekerjaan dan kurangnya program-program yang mendukung lahirnya jiwa kewirausahaan. Tapi apabila pemerintah melakukan peran serta dalam menyediakan lapangan pekerjaan yang bersifat padat karya dan mampu membangun iklim kewirausahaan untuk membantu mendorong produktifitas masyarakat. Maka masalah kepadatan penduduk justru mampu menjadi modal penggerak pembangunan ekonomi wilayah.

Tabel 3.

Data Jumlah Angakatan Kerja, Kesempatan Kerja dan Tingkat Kesempatan Kerja Tahun 2013-2017

\begin{tabular}{cccc}
\hline Tahun & $\begin{array}{c}\text { Jumlah Angkatan Kerja } \\
\text { (Orang) }\end{array}$ & $\begin{array}{c}\text { Kesempatan Kerja } \\
\text { (Orang) }\end{array}$ & $\begin{array}{c}\text { Tingakat } \\
\text { Kesempatan Kerja } \\
\text { (Persen) }\end{array}$ \\
\hline 2013 & 441.880 & $429 . .844$ & 97,28 \\
2014 & 472.103 & 461.133 & 97,68 \\
2015 & 485.74 & 468.515 & 96.46 \\
2017 & 451.465 & 501.909 & 9737 \\
\hline
\end{tabular}

Sumber :Data Diolah, 2018.

Jumlah angkatan kerja di Kota Denpasar di tahun 2013 adalah sebesar 441.880 orang dan terus mengalami peningkatan sampai sebesar 515.464 orang di 
tahun 2017. Peningkatan jumlah angkatan kerja tersebut juga di iringi dengan peningkatan kesempatan kerja yakni 429.844 orang tahun 2013 dan pada tahun 2017 yaitu sebesar 501.909 orang. Adapun dilihat dari peningkatan kesempatan kerja mengalami fluktuatif yakni 97,28 persen pada tahun 2013, mengalami peningkatan menjadi 97,68 persen di tahun 2014, lalu pada tahun 2015 mengalami penurunan menjadi 96,46 persen dan terakhir di tahun 2017 mengalami peningkatan menjadi 97,37 persen.

Peningkatan jumlah angkatan kerja itu disebabkan karna meningkatknya jumlah penduduk pencari kerja dan siap untuk bekerja di pasar kerja.Permasalahan ini juga disebabkan meningkatnya angka jumlah kesempatan kerja yang tidak diiringi dengan jumlah angkatan kerja yang tersedia, sehingga hal ini dapat berpotensi menimbulkan permasalahan pengangguran dan tingkat kemsikinan di Kota Denpasar. Adanya program-program pemerintah yang mendukung masyarakat dalam menyedikan kesempatan kerja, menciptakan pelatihan-pelatihan kewirausahaan serta membangun program kreativitas, tentu dapat mendorong tumbuhnya semangat entrepreneurship masyarakat yang nantinya mampu menciptakan kesempatan kerja bagi masyakat itu sendiri agar dapat lebih produktif dan mengatasi permasalahan pengangguran penduduk nantinya(Jensen \& Mecking, 1976)

Tingkat pertumbuhan ekonomi di suatu daerah biasanya diukur menggunakan PDRB atas dasar harga konstan.PDRB saat ini dapat dijadikan patokan penting dalam pembangunan suatu wilayah.Dalam hal ini PDRB adalah gambaran terhadap suatu keadaan perekonomian daerah. Semakin tinggi 
pertumbuhan ekonomi yang dicapai suatu wilayah maka hal itu menandakan semakain baik kegiatan ekonomi yang didapat dari laju PDRB atas dasar harga konstan ( Suartha \& Yasa, 2017)

Tabel 4.

Laju Pertumbuhan Produk Domestik Regional Bruto Atas Dasar Harga Konstan 2010 di Kota Denpasar Tahun 2012-2017

\begin{tabular}{cc}
\hline Tahun & Pertumbuhan PDRB (persen) \\
\hline 2012 & 6.78 \\
2013 & 6.96 \\
2014 & 7.00 \\
2015 & 6.19 \\
2017 & 6.50 \\
\hline Rata-rata & $\mathbf{6 . 6 9}$ \\
\hline
\end{tabular}

Sumber :Data Diolah, 2018.

Data tingkat pertumbuhan Produk Domestik Regioanl Bruto (PDRB) Kota Denpasar berfluktuatif dengan rata-rata 6.96 persen. Pada periode 2012-2016 pertumbuhan PDRB Kota Denpasar mengalami pertumuhan tinggi yaitu di tahun 2014 sebesar 7.00 persen atau mengalami peningkatan dari tahun sebelumnya sebesar 0.04 persen, dan mengalami pertumbuhan PDRB terendah yaitu di tahun 2015 sebesar 6.19 persen atau mengalami penururnan sebesar 0.81 persen dari tahun sebelumnya. PDRB yang mengalami peningkatan dan penurunan tersebut dikarenkan oleh kondisi wilayah kota Denpasar seperti tingkat daya beli masyarakat, lapangan usasah, inflasi ,deflasi dan peranan masing-masing kegiatan ekonomi.

Rumah makan yang berkembang di Kota Denpasar yang tersebar di empat kecamatan yaitu sebanyak 383 pada tahun 2013, menurun menjadi sebesar 368 tahun 2014, sebesar 376 tahun 2015 dan 2016, serta sebesar 385 usaha tahun 2017. Industri kuliner rumah makan secara umum yang berkembang di Kota 
Denpasar yaitu yang mengahasilkan produk-produk olahan kuliner rakyat seperti : nasi padang, nasi campur, babi guling, ayam betutu, sate gule, bakso, nasi lawar, sate lilit, siobak, dan lain sebagainya.

Responden rentangan umur 20-29 tahun lebih dominan mendirikan usaha rumah makan angkringan yang varian menunya cukup beragam dari menu cita rasa nusantara lokal seperti be genyol dan iga babi bakar hingga menu yang digemari kalangan anak muda seperti ayam geprek, mie pedas, nasi goreng, ayam bakar dan lain sebagainya, sedangkan umur 30-49 tahun lebih didominasi oleh responden yang mendirikan rumah makan kategori permanen serta telah terkenal keberadaannya, seperti rumah makan nasi ayam betutu, lawar, soto, dan lainnya. Serta rentangan umur 55-60+ tahun lebih didominasi oleh reponden yang produknya telah dikenal oleh konsumen seperti rumah makan nasi babi guling, siobak, dan lainnya yang telah memiliki konsumen tetap serta produknya telah diwarisakan dari turun temurun yang memiliki ciri khas rasa, tampilan, tempat, dan sensasi pelayanan yang berbeda dari rumah makan lainnya

Mayoritas responden pada penelitian ini yaitu berpendidikan SMA dan Perguruan Tinggi. Di era industri gelombang ke empat ini bahwasannya perlu mengamanatkan pendidikan yang inklusi, dimana pendidikan harus dapat dinikmati oleh seluruh lapisan masyarakat, dari jenjang pendidikan terendah hingga jenjang pendidikan perguruan tinggi secara merata dan berkeadalian, sehingga kedepan generasi selanjutnya dapat mampu menjadi generasi berkualitas, memiliki soft skill dan hard skill yang baik dalam melakukan pengembangan usaha kuliner yang produktif.Responden pelaku usaha kuliner 
rumah makan di Kota Denpasar lebih di dominasi oleh lama operasional 0-9 tahun.Hal ini berarti bahwa di era milenial saat ini menjalankan usaha kuliner merupakan suatu bentuk kegiatan usaha yang mudah dikembangkan karena menyesuaikan dengan selera dan tren masyarakat saat ini.Sehingga kegiatan operasional usaha industri kuliner rumah makan dapat bertahan keberlanjutannya apabila dapat berinovasi dan mampu menarik selera konsumen.

Berdasarkan penelitian yang dilakukan dilapangan, diketahui bahwa responden yang memiliki pengalaman usaha 0-4 tahun didominasi memiliki usaha rumah makan dalam bentuk angkringan yang menjual produk-produk olahan makanan yang tren dikalangan anak muda seperti ayam geprek, mie-mie pedas, nasi goreng, dan lainnya. Lama usaha industri kuliner rumah makan rentangan waktu 5-9 tahun lebih didominasi oleh olahan produk makanan kuliner yang berbasis rumah makan yang telah menetap pada suatu wilayah dan sedang-sedang ramainya dikunjungi oleh siswa/mahasiswa dan pekerja ketika istirahat, seperti rumah makan betutu, babi guling, masakan padang, dan lainnya. Sedangkan lama usaha rentangan waktu 15 tahun ke atas lebih didominasi oleh industri kuliner rumah makan yang telah menetap dan telah memiliki nama terkenal di mata konsumen, sehingga konsumen yang mengkonsumsi produknya, benar-benar telah memiliki ketergantungan dalam mengkonsumsinya, rumah makan seperti ini yaitu seperti nasi babi guling grenceng, nasi babi guling men weti, nasi babi guling men repot, nasi men lotri, bakso, ayam bakar, dan lainnya yang telah buming sejak dulu dimata konsumen. 
Bahan baku dalam penelitian ini adalah keseluruhan bahan-bahan yang dipergunakan oleh industri kuliner rumah makan dalam menunjang kegitan produksinya. Bahan baku ini seperti beras, sayur-sayuran, daging, ikan, buahbuahan, dan lain sebagainya sesuai dengan kebutuhan bahan baku yang dipergunakan untuk menunjang kebutuhan industri rumah makan tersebut. Dalam penelitian ini, sumber bahan baku yang dominan dipergunakan oleh rumah makan di Kota Denpasar adalah bahan baku yang bersumber dari lokal wilayah bali yang artinya bahwa industri rumah makan yang akan di Kota Denpasar lebih memperkuat dan mendukung posisi tawar/bergainning produk lokal bali sehingga mampu memberikan multiflier effect bagi keberlanjutan produsen-produsen lokal.

Responden pelaku usaha industri kuliner rumah makan memiliki pendapatan rata-rata berkisar antara $\mathrm{Rp} 26.000 .000-51.999 .000$. Hal tersebut berarti bahwa selama sebulan industri kuliner rumah makan di Kota Denpasar rata-rata berpendapatan sekitar Rp 26.000.000-51.999.000, yang tergolong berada di atas UMK Kota Denpasar, serta pendapatan tersebut dapat memiliki multiflier effect bagi pekerja dan sumbangan pajak kepada pemerintah daerah.

Tabel 5.

Hasil Uji Kelayakan Model Struktur 1

\begin{tabular}{llrrrrr}
\hline Model & & Sum of Squares & Df & Mean Square & F & \multicolumn{1}{c}{ Sig. } \\
\hline 1 & Regression & 8.429 & 3 & 2.810 & 17.425 & $.000^{\mathrm{a}}$ \\
& Residual & 12.093 & 75 & .161 & & \\
& Total & 20.522 & 78 & & & \\
\hline
\end{tabular}

Sumber :Data Diolah, 2019

Nilai signifikansi sebesar 0,000 yang lebih kecil dari nilai $\alpha=0,05$ sehingga model yang digunakan pada penelitian ini layak. Hasil ini memberikan makna bahwa penggunaan bahan baku, kewirausahaan dan pengalaman kerja mampu 
memprediksi atau menjelaskan produksi industri kuliner rumah makan di Kota Denpasar. Ini berarti model pada struktur 1 dapat digunakan untuk analisa lebih lanjut atau dengan kata lain model dapat digunakan untuk memproyeksikan, karena hasil goodness of fit kategori baik dengan nilai $\mathrm{F}$ sebesar 17.425 dengan nilai signifikasi sebesar 0,000 .

Tabel 6.

Hasil Uji Kelayakan Model Struktur 2

\begin{tabular}{rlrrrrr}
\hline Model & & Sum of Squares & Df & \multicolumn{1}{c}{ Mean Square } & F & \multicolumn{1}{c}{ Sig. } \\
\hline 1 & Regression & 9.940 & 4 & 2.485 & 17.376 & $.000^{\mathrm{a}}$ \\
& Residual & 10.582 & 74 & .143 & & \\
& Total & 20.522 & 78 & & & \\
\hline
\end{tabular}

Sumber : Data Diolah, 2019

Nilai signifikasi sebesar 0,000 yang lebih kecil dari nilai $\alpha=0,05$ maka model yang digunakan pada penelitian ini adalah layak. Hasil ini memberikan makna bahwa pengaruh bahan baku, kewirausahaan, pengalaman kerja dan produksi mampu memprediksi atau menjelaskan variabel pendapatan industri kuliner rumah makan di Kota Denpasar, ini berarti model pada struktur 2 dapat digunakan untuk analisa lebih lanjut atau dengan kata lain model dapat digunakan untuk memproyeksikan karena hasil goodness of fitnya baik dengan nilai $\mathrm{F}$ hitung sebesar 17.376 dengan nilai signifikasi sebesar 0,000

Tabel 7.

Hasil Uji Regresi Bahan Baku, Kewirausahaan Dan Pengalaman Kerja Terhadap Produksi Industri Kuliner Rumah Makan Di Kota Denpasar.

\begin{tabular}{|c|c|c|c|c|c|c|}
\hline \multirow[b]{2}{*}{ Model } & & \multicolumn{2}{|c|}{ Unstandardized Coefficients } & \multirow{2}{*}{$\begin{array}{c}\text { Standardized } \\
\text { Coefficients } \\
\text { Beta }\end{array}$} & \multirow[b]{2}{*}{$\mathrm{T}$} & \multirow[b]{2}{*}{ Sig. } \\
\hline & & $\mathrm{B}$ & Std. Error & & & \\
\hline \multirow[t]{4}{*}{1} & (Constant) & -1.288 & 1.292 & & -.997 & .322 \\
\hline & Bahan baku & .506 & .078 & .582 & 6.515 & .000 \\
\hline & Kewirausahaan & .300 & .127 & .219 & 2.369 & .020 \\
\hline & Pengalaman kerja & .000 & .001 & .016 & .172 & .864 \\
\hline
\end{tabular}


Sumber : Data Diolah, 2019

Variabel bahan baku $\left(\mathrm{X}_{1}\right)$ dengan nilai sig. $<0,05$, hal ini menunjukkan bahan baku berpengaruh positif dan signifikan terhadap produksi industri kuliner rumah makan di Kota Denpasar. Variabel kewirausahaan $\left(\mathrm{X}_{2}\right)$ dengan nilai sig. $0.020<0,05$, ini berarti bahwa kewirausahaan berpengaruhpositif signifikan terhadap produksi industri kuliner rumah makan di Kota Denpasar, dan untuk variabel Pengalaman Kerja $\left(\mathrm{X}_{3}\right)$ dengan nilai sig. 0,864> 0,05, menunjukkan bahwa pengalaman kerja tidak berpengaruh signifikan terhadap produksi industri kuliner rumah makan di Kota Denapasar.

Tabel 8 menunjukkan bahwa variabel bahan baku $\left(\mathrm{X}_{1}\right)$ dengan nilai sig. $0,000<0,05$, hal ini berarti variabel bahan baku berpengaruh positif dan signifikan terhadap pendapatan industri kuliner rumah makan di Kota Denpasar.Variabel Kewirausahaan $\left(\mathrm{X}_{2}\right)$ dengan nilai sig $0,020<0,05$, ini berarti kewirausahaan berpengaruh positif dan signifikan terhadap pendapatan industri kuliner rumah makan di Kota Denpasar. Variabel pengalaman kerja $\left(\mathrm{X}_{3}\right)$ dengan nilai sig. 0,809 $>0,05$, ini berarti pengalaman kerja tidak berpengaruh signifikan terhadap pendapatan industri kuliner rumah makan di Kota Denpasar. Variabel Produksi $\left(\mathrm{Y}_{1}\right)$ dengan nilai sig. $0,002<0,05$, yang artinya produksi industri kuliner rumah makan berpengaruh positif dan signifikan terhadap pendapatan industri kuliner rumah makan di Kota Denpasar. 
Tabel 8.

Hasil Uji Regresi Bahan Baku, Kewirausahaan, Pengalaman Kerja Dan Produksi Terhadap Pendapatan Industri Kuliner Di Kota Denpasar

\begin{tabular}{llrrrrrr}
\hline & & \multicolumn{2}{c}{$\begin{array}{c}\text { Unstandardized } \\
\text { Coefficients }\end{array}$} & \multicolumn{2}{c}{$\begin{array}{c}\text { Standardized } \\
\text { Coefficients }\end{array}$} & & \\
\cline { 3 - 6 } Model & & \multicolumn{1}{c}{ B } & \multicolumn{2}{c}{ Std. Error } & Beta & \multicolumn{1}{c}{ S } & \multicolumn{1}{c}{ Sig. } \\
\hline \multirow{2}{*}{1} & (Constant) & .025 & 1.282 & & .019 & .985 \\
& Bahan baku & .425 & .077 & .488 & 5.491 & .000 \\
& Kewirausahaan & .284 & .119 & .206 & 2.373 & .020 \\
& Pengalaman kerja & .000 & .001 & .021 & .242 & .809 \\
& Produksi & $2.366 \mathrm{E}-5$ & .000 & .288 & 3.250 & .002 \\
\hline Sumber & : & & & & & &
\end{tabular}

Sumber : Data Diolah, 2019

Berdasarkan hasil perhitungan koefisein diterminasi total maka diproleh bahwa keragaman data yang dapat dijelaskan oleh model adalah sebesar 0,697 atau degan kata lain informasi yang terkandung dalam data sebesar 69,7 persen dapat dijelaskan oleh model, sedangkan sisanya yaitu 30,3 persen dijelaskan oleh variabel lain yang tidak terdapat dalam model.

Berdasarkan hasil penelitian yang menunjukkan bahwa, bahan baku berpengaruh positif dan signifikan terhadap produksi industri kuliner rumah makan di Kota Denpasar. Artinya bahwa jumlah stok bahan baku yang dimiliki oleh pelaku usaha berpengaruh terhadap jumlah produksi yang dihasilkan. Semakin banyak stok bahan baku yang dipergunakan untuk menunjang kegiatan produksi, maka akan semakin banyak hasil produksi yang dihasilkan, hal tersebut dikarenakan bahwa banyaknya tersedia bahan baku untuk dapat menghasilkan berbacam-macam produk makanan serta akan berdampak bagi penjualannya(Jong \& Wennekers, 2008). Begitu sebaliknya ketika jumlah stok bahan baku yang dimiliki oleh pengusaha sedikit maka akan semakin sedikit kemampuannya untuk 
dapat menghasilkan output yang maksimal, dikarenakan jumlah stok bahan baku yang dimilikinya sedikit, hal tersebut juga dapat berdampak bagi volume penjualan berbagai jenis macam produk yang dihasilkannya(Florida. \& Kenney, 1986)

Tersedianya stok bahan baku yang minim bisa mengakibatkan proses produksi terhambat dan menimbulkan keterlambatan dalam kegiatan produksi. Begitu sebaliknya jika persediaan bahan baku berlebihan maka akan terjadi penumpukan jumlah bahan baku, serta kualitas bahan baku yang akan mulai menurun kualitasnya dalam jangka panjang. Jadi tersedianya stok bahan baku harus dapat menyesuaikan dengankemampuan produksi secara berkelanjutan (Chaudhary \& Perjev, 2016)

Hasil penelitian menunjukkan bahwa kewirausahaan memiliki pengaruh positif dan signifikan terhadap produksi industri kuliner rumah makan khas balidi Kota Denpasar.Hal ini berarti bahwa kemampuan inovasi yang dimiliki oleh pelaku usaha berdampak terhadap jumlah produksi yang dihasilkan ataupun yang terjual.Pada penelitian ini kemampuan kewirausahaan (inovasi) yang dimiliki oleh pelaku industri rumah makan khas bali telah diterapkan pada produksi yang dihasilkan seperti melakukan inovasi terhadap olahan rasa makanan yang bervariasi dan beranekaragam, kemudian inovasi pada penyajian makanan dan tatanan produk beserta tatanan tempat industri kuliner yang lebih menjaga kebersihan dan pelayanan yang optimal sehingga dapat menarik minat konsumen untuk terus berkunjung dan membeli produk yang dihasilkan.(Hajej, Rezg, \& Gharbi, 2018). 
Inovasi terhadap teknikpemasaran yang dilakukan dengan memadukan kemajuan dan kecanggihan teknologi di era saat ini seperti melakukan pemasaran melalui media sosial facebook, instagram, web, dan lain sebagainya, serta telah dapat bekerja sama dengan aplikasi pemesanan online seperti Gojek dan Grab Food yang dapat berdampak bagi semakin luasnya jangkuan pemasaran, dapat meningkatkan penjualan dan pendapatan yang di hasilkan oleh pelaku usaha kuliner.Hasil penelitian menunjukkan bahwa pengalaman kerja tidak berpengaruh positif dan signifikan terhadap produksi industri kuliner rumah makan di Kota Denpasar.Hal ini berarti bahwa pengalaman kerja yang dimiliki oleh pelaku usaha tidak menjamin banyaknya jumlah produksi yang dihasilkan serta banyaknya produksi yang laku terjual. Namun seorang pelaku usaha barupun dapat menghasilkan output dan penjualan produksi yang maksimal ketika pelaku usaha tersebut dapat menganalisis dan menerapkan konsep bisnis yang baik dalam menjalankan usahanya (Bernabe, 2009).

Menurut Putra \& Kartika (2019), pengalaman kerja merupakan ukuran mengenai lama waktu atau masa kerja seseorang sehingga mereka dapat memahami tugas dan fungsi dalam pekerjaannya. Pengalaman kerja identik dengan lamanya waktu dalam menekuni pekerjaan tersebut, tingkat pengetahuan teknologi, serta penguasaan terhadap aspek-aspek perlengkapan dan peralatan dalam bekerja/usaha.Pengalaman kerja mencerminkan tingkat penguasaan, pemahaman, atau pengetahuan yang dimiliki oleh seseorang dalam menjalankan kegiatan usahanya.Dengan dimilikinya berpengalamannya seseorang dalam menjalankan kegiatan usaha berarti mencerminkan orang tersebut telah dapat 
mengusai bidang pekerjaan yang ditekuninya. Dalam penelitian ini, pelaku usaha industri kuliner rumah makan, lebih didominasi oleh berpendidikan SMA dan Perguruan Tinggi, jadi mereka memiliki pengetahuan/pemahaman yang dalam menjalankan kegiatan usaha rumah makan walaupun pengelaman kerja mereka tergolong baru khususnya bagi kaum milenial yang lebih mengetahui selera masyarakat yang lebih kekinian.

Kenyataan dilapangan mulai banyaknya bermunculan pelaku-pelaku usaha kuliner rumah makan kategori baru serta mereka dapat menarik hati konsumen dan dapat sukses dalam menjalankan usahanya, walaupun pengalaman yang dimiliki oleh mereka tergolong baru dalam menjalankan usaha.Hal tersebut dikarenakan mereka dapat menawarkan cita rasa yang sedang tren saat ini, konsep tempat nyaman, kreativitas produk yang dihasilkan, dan jangkaun media pemasaran produk yang dapat dikenal mudah dan mampu menarik konsumen dapat membeli dan mengunjungi usaha yang dimilikinya tersebut.Sehingga pengalaman kerja yang dimiliki oleh pelaku usaha, tidak menjadi jaminan bagi kesuksesan penjualan dan produksi yang dapat dihasilkannya.

Berdasarkan hasil penelitian menunjukkan bahwa bahan baku berpengaruh positif dan signifikan terhadap pendapatan industri kuliner rumah makan di Kota Denpasar. Artinya bahwa bahan baku yang dimiliki oleh pelaku usaha berpengaruh terhadap proses produksi dalam menghasilkan output yang maksimal. Semakin banyak jumlah stok bahan baku yang dimiliki maka akan semakin banyak produk yang dijual dan berpengaruh terhadap pendapatan yang diterima oleh pelaku usaha. Sedangkan sedikitnya jumlah stok bahan baku yang 
dimiliki untuk menunjang produksi maka hasil produksi yang dijual kepada konsumen akan kurang maksimal/sedikit sehingga berpengaruh terhadap sedikitnya jumlah pendapatan yang diterima oleh pelaku usaha industri kuliner rumah makan di Kota Denpasar.

Bahan baku merupakan bahan yang membentuk bagian yang menyeluruh untuk menunjang kelancaran kegiatan produksi, tersedianya bahan baku dalam jumlah yang cukup dan berkesinambungan dengan harga yang dapat dijangkau (efisien), maka pada akhirnya akan dapat meningkatkan produksi serta meningkatkan jumlah pendapatan usaha yang diperoleh oleh pelaku usaha (Pratiwi, 2014).

Penelitian ini menunjukkan hasil bahwa kewirausahaan berpengaruh positif dan signifikan terhadap pendapatan industri kuliner rumah makan khas balidi Kota Denpasar.Artinya bahwa kemampuan kewirausahaan dalam bentuk inovasi yang diterapkan oleh pelaku usaha mampu mepengaruhi besaran jumlah pendapatan yang dihasilkan.Tinggi tingkat kewirausahaan (inovasi) yang diterapkan dalam menjalankan usaha rumah makan maka berpengaruh pada peningkatan jumlah pendapatan yang diterima. Menurut penelitian Liu \& Lawell (2015)yang menyatakan bahwa kemampuan kewirausahaan (inovasi) yang dimiliki seseorang seperti kurva "U", apabila inovasi tergolong rendah maka akan dapat merununkan distribusi pendapatan, sedangkan ketika kemampuan inovasi tinggi atau dapat diterapkan dengan baik dalam menjalankan usaha maka akan dapat meningkatkan pendapatan yang diterima oleh oleh pelaku usaha. (Astuty \& Wibowo, 2018). 
Berdasarkan hasil penelitian, menunjukkan bahwa pengalaman kerja tidak berpengaruh signifikan terhadap pendapatan industri kuliner rumah makan di Kota Denpasar.Artinya bahwa pengalaman kerja yang dimiliki oleh pelaku usaha industri kuliner rumah makan tidak berpengaruh terhadap besaran jumlah pendapatan yang diterima oleh pelaku usaha.Berpengalaman atau tidaknya pelaku usaha dalam menjalankan usaha tidak menjadi jaminan bagi besar atau sedikitnya jumlah pendapatan yang diterima oleh pelaku usaha industri kuiner rumah makan di Kota Denpasar.

Berdasarkan hasil penelitian menunjukkan bahwa produksi berpengaruh positif dan signifikan terhadap pendapatan pelaku industri kuliner rumah makan di Kota Denpasar.Artinya bahwa kemampuan produksi yang dihasilkan oleh pelaku usaha berpengaruh terhadap jumlah pendapatan yang dihasilkan. Semakin tinggi jumlah produksi yang dihasilkan dalam menjalankan kegiatan usaha yang berdampak terhadap peningkatan penjualan maka akan semakin besar jumlah pendapatan yang akan diterima oleh pelaku usaha, sedangkan, semakin sedikit jumlah produksi yang dihasilkan dan yang laku terjual, makan akan semakin sedikit pendapatan yang diterima oleh pelaku usaha industri kuliner rumah makan di Kota Denpasar.

Oleh karena Z hitung sebesar 6,505> 1,96 artinya bahwa bahan baku berpengaruh secara tidak langsung dan signifikan terhadap pendapatan melalui produksi. Artinya bahwa ketika jumlah stok bahan baku yang dimiliki oleh pelaku usaha ditingkatkan untuk menunjang kegiatan produksi maka akan berdampak pada peningkatan pendapatan yang diterima oleh pelaku usaha industri kuliner 
rumah makan di Kota Denpasar, hal tersebut dikarenakan bahwa ketika jumlah produksi meningkat yang artinya bahwa terdapat peningkatan dari segi penjualannya, maka akan memperbanyak jumlah stok bahan baku untukmenunjang kegiatan produksi dalam menghasilkan output yang maksimal serta akan berdampak bagi penerimaan pendapatan oleh pelaku usaha.

Oleh karena $\mathrm{Z}$ hitung sebesar 2,366< 1,96 artinya kewirausahaan berpengaruh secara tidak langsung dan signifikan terhadap pendapatan melalui produksi. Hal ini berarti bahwa ketika kewirausahaan dalam bentuk inovasi dapat diterapkan atau diimplementasikan dengan baik untuk menunjang kelancaran dan pembaharuan jalannya usaha, maka akan berdampak bagi peningkatan produksi dan penjualan serta meningkatknya pendapatan yang diterima oleh pelaku usaha kuliner rumah makan di Kota Denpasar.

Oleh karena $\mathrm{Z}$ hitung sebesar $0<1,96$ artinya bahwa pengalaman kerja tidak berpengaruh secara tidak langsung terhadap pendapatan melalui produksi. Artinya bahwa pengalaman kerja yang dimiliki oleh pelaku usaha tidak menjadi jaminan bagi pelaku usaha tersebut untuk dapat menghasilkan produksi dan penjualan yang maksimal serta dapat mendorong peningkatan pendapatan, namun pelaku usaha yang kurang berpengalaman juga dapat menghasilkan produksi yang optimal dan penjualan yang maksimal bila pelaku usaha tersebut dapat mengatahui dan menganalisis minat/selera konsumen dengan baik, kemudian mengemasnya dalam suatu konsep inovasi seperti contoh adanya varian level pedas dengan penamaan yang unik pada menu makanan yang disediakan. Hal 
tersebut dapat berdampak bagi peningkatan penjualan dan pendapatan yang diterima oleh pelaku usaha.

Nilai koefisien bahan baku terhadap produksi sebesar 0,582 artinya apabila bahan baku meningkat 1 poin maka produksi akan mengalami peningkatan sebesar 0,582 poin. Berdasarkan hasil tersebut maka variabel yang lebih berpengaruh terhadap produksi adalah penggunaan bahan baku.Nilai koefisien bahan baku terhadap pendapatan sebesar 0,488 artinya apabila bahan baku meningkat 1 poin maka pendapatan akan bertambah sebesar 0,488 poin. Koefisien kewirausahaan terhadap pendapatan sebesar 0,206 artinya apabila pelaku usaha kuliner rumah makan menerapkan prinsip kewirausahaan yang inovatif naik 1 poin, maka pendapatan akan bertambah 0,206 poin. Berdasarkan hasil tersebut maka variabel yang lebih berpengaruh terhadap pendapatan adalah produksi.

Pengaruh tidak langsung bahan baku terhadap pendapatan melalui produksi sebesar 0,184, mempunyai arti bahwa pengaruh tidak langsung bahan baku terhadap pendapatan melalui produksi adalah sebesar 18,4 persen. Pengaruh tidak langsung kewirausahaan terhadap pendapatan melalui produksi sebesar 0,300, mempunyai arti bahwa pengaruh tidak langsung kewirausahaan terhadap pendapatan melalui produksi 30,0 persen. Pengaruh tidak langsung pengalaman kerja terhadap pendapatan melalui produksi sebesar 0 , mempunyai arti bahwa pengaruh tidak langsung pengalaman kerja terhadap pendapatan melalui produksi adalah sebesar 0 persen.

Implikasi dari hasil penelitian ini industri kuliner rumah makan merupakan industri kuliner rumah makan yang menyajikan/menjual makanan-makanan baik 
lokal maupun suatu daerah seperti nasi padang, ayam geprek ,nasi lawar, sate gule, nasi betutu, siobak, dan lain sebagainya yang memiliki cita rasa nusantara sarta dapat dijangkau oleh seluruh lapisan masyarakat. Kepemilikan bahan baku menjadi faktor penentu bagi keberlangsungan industri kuliner, tersedianya stok bahan baku yang maksimal dapat menghasilkan produksi yang maksimal dan bernekaragam jenis olahan makanan yang dapat dijual sehingga dapat mendorong peningkatan penjualan dan pendapatan, sedangkan sedikitnya jumlah stok bahan baku yang dimiliki, maka kemampuan produksi/menghasilkan produk akan semakin kecil sehingga akan berpengaruh terhadap rendahnya pendapatan yang diperoleh oleh pelaku usaha industri kuliner rumah makan khas bali di Kota Denpasar.

Terkait dengan kewirausahaan (inovasi) yang dimiliki oleh pelaku usaha, apabila pelaku usaha industri kuliner rumah makan di Kota Denpasar mampu menerapkannya dengan baik dalam menjalankan usaha khususnya dalam proses produksi yang dilakukan untuk menghasilkan output yang maksimal dan bervariasi dan beranekaragam maka akan dapat menarik minat konsumen dan meningkatkan penjualan dan pendapatan yang diperoleh, sedangkan apabila jiwa kewirausahaan (inovasi) tersebut tidak dapat diterapkan dengan baik dalam menjalankan usaha maka tidak akan berdampak bagi jumlah produksi yang terjual dan pendapatan yang diperoleh.

Berpengalaman atau tidaknya pelaku usaha dalam menjalankan usahanya tidak menjadi faktor penentu dalam menghasilkan produksi yang maksimal dan meningkatkan penjualannya.Di era millenial saat ini mengetahui situasi pasar dan 
selera konsumen serta mampu menerapkan konsep penjualan yang kekinian menjadi hal penting dalam menghasilkan produk yang maksimal dalam meningkatkan penjualan dan pendapatan yang diperoleh oleh pelaku usaha industri kuliner rumah makan secara umum, sehingga mereka dapat mengembangkan usahanya secara berkelanjutan dan dapat meningkatkan kesejahteraannya.

\section{SIMPULAN}

Berdasarkan hasil penelitian tersebut di atas, simpulan yang dapat diberikan adalah Bahan baku dan kewirausahaan berpengaruh positif dan signifikan terhadap produksi industri kuliner rumah makan di Kota Denpasar. Sedangkan pengalaman kerja tidak berpengruh signifikan terhadap produksi industri kuliner rumah makan di Kota Denpasar.Bahan baku, kewirausahaan dan produksi berpengaruh positif dan signifikan terhadap pendapatan industri kuliner rumah makan di Kota Denpasar. Sedangkan pengalaman kerja tidak berpengaruh signifikan terhadap pendapatan industri kuliner rumah makan di Kota Denpasar.Bahan baku dan kewirausahaan berpengaruh secara tidak langsung terhadap pendapatan melalui produksi, sedangkan pengalaman kerja tidak berpengaruh secara tidak langsung dan signifikan terhadap pendapatan melalui produksi industri kuliner rumah makan di Kota Denpasar.

Berdasarkan simpulan tersebut, maka saran yang dapat diberikan yaitu Bagi pemerintah semoga penelitian ini dapat menjadi bahan masukan dan rekomendasi dalam pembuatan kebijakan kedepan dalam pemberdayaan industri kuliner rumah 
makan di Kota Denpasar khususnya bagi industri kuliner rumah makan yang kebanyakan masih tradisional, sehingga eksistensinya dalam menjual produk makanan tetap terjaga keberlanjutannya. Pemberian pelatihan kewirausahaan sangat diperlukan bagi pelaku usaha dan pekerja industri kuliner rumah makan sehingga merekadapat menerapkan inovasi-inovasi, kreativitas, dan pemanfaatan kemajuan teknologi terhadap produk yang hasilkan sehingga mereka dapat meningkatkan penjualan dan pendapatannya.

Bagi pelaku usaha diharapkan penelitian ini dapat menjadi bahan masukan dan evalusi kedepan dalam menjalankan kegiatan usaha yang lebih baik khususnya dalam menerapkan jiwa kewirausahaan serta memperdalam pengalaman di bidang kuliner khususnya dalam menerapkan kemampuan dalam berinovasi, kreativitas, dan pemanfaatan teknologi modern yang lebih baik dalam menjalankan usaha

\section{REFERENSI}

Astuty, A. R., \& Wibowo, L. A. (2018). Breakthrought in Indonesia Creative Industry Throught Soft Innovation. International Journal of Enteprenuership, 22(2), 1-20.

Bernabe, E. (2009). Income, Income Inequality, Dental Caries and Dental Care Levels: An Ecological Study in Rich Countries. International Journal Departement of Epidemiology and Public, 9(43), 1-20.

Cannice, M. V, Allen, J. P., \& Tarrazo, M. (2016). What Do Venture Capitalists Think of Venture Capital Research? Bulletin of Indonesian Economic Studies, 10(1), 1-20.

Chaudhary, A. N. A., \& Perjev, M. (2016). Productivity Analysis of Steel Industri of India: A Case Study of Steel Authority of India Ltd. International Journal of Commerce, Business and Menegement, 5(1), 2319-2828.

Hajej, Z., Rezg, N., \& Gharbi, A. (2018). Quality Issue in Forecasting Problem of Production and Maintenance Policy for Production Unit. International Journal of Production Research, 1(1), 6147-6163.

Jong, \& Wennekers. (2008). Conceptualizing Entreprenual Employee Behaviour. 
SMEs and Entreprenuership Programme Finance, 1(1), 1-20.

Kuyvenhoven, J. C. (2006). Capital Utilisation in Indoensian Medium and Large Scale Manufacturing. Bulletin of Indoensian Economic Studies, 5(1), 1-20.

Liu, Q., \& Lawell, C.-Y. C. L. (2015). The Effect of Innovation on Income Inequality in China. Journal of Economics Business, 1(1), 1-12.

Lyon, W. ., Lumpkin, T. ., \& Dess, G. . (2000). Enchaing Entrepreneural Orientation Research: Operationalizing and Measuring a Key Strategis Decesion Making Process. Journal of Manegement, 26(5), 1-20.

Moissevea, M. (2009). The Dyanmic of Production Output. Jurnal of International Research Publication Economy and Businnes, 4(2), 186-207.

Muliani, N. M. S., \& Suresmiathi, A. A. A. (2015). Pengaruh Pengalaman KerjaTerhadap Produktivitas Pengerajin untuk Menunjang Pendapatan Pengerajin Ukiran. E-Jurnal Ekonomi Pembangunan Universitas Udayana, 5(5), 1-30.

Mulyadi, D., \& Hartono, D. (2018). Pengaruh Efisiensi Energi Listrik pada Sektor Industri dan Komersial terhadap Permintaan Listrik di Indonesia. Jurnal Ekonomi Kuantitatif Terapan, 11(1), 1-30.

Ningsih, N. M. C., \& Indrajaya, I. G. B. (2015). Pengaruh Modal dan Tingkat Upah terhadap Nilai Produksi serta Penyerapan Tenaga Kerja pada Industri Kerajinan Perak. Jurnal Ekonomi Kuantitati Terapan, 8(1), 1-23.

Oforoi, G. (2006). Finance For Small And Medium Enterpries In Nigeria, Agricultural Credit Guarantee Scheme Fund. Journal of International Farm Management, 3(2), 67-77.

Pratiwi, A. M. (2014). Analisis Efisiensi dan Produktivitas Industri Besar dan Sedang di Wilayah Provinsi Bali (Pendekatan Stochastic Frontier Analysis). Jurnal Ekonomi Kuantitatif Terapan, 7(1), 73-79.

Putra, P. M. S., \& Kartika, N. (2019). Analisis Pengaruh Modal, Umur, Jam Kerja, Pengalaman Kerja, dan Pendidikan terhadap Pendapatan Nelayan di Kedonganan. Jurnal Ekonomi Pembangunan Universitas Udayana, 2(2), 120.

Sancoko, A. H. (2015). Strategi Pengembangan Bisnis Usaha Makanan dan Minuman pada Depot Time to Eat Surabaya. Jurnal AGORA, 13(1), 1-20.

Suartawan, K., \& Purbadharmaja, I. B. (2017). Pengaruh Modal Bahan Baku terhadap Pendapatan Melalui Produksi Pengerajin Patung Kayu di Kecamatan Sukawati Kabuapten Gianyar. E-Jurnal Ekonomi Pemabangunan, 6(9), 1-20.

Suartha, I. N. (2016). Faktor-Faktor yang Mempengaruhi Tingginya Laju Pertumbuhan dan Implementasi Kebijakan Penduduk di Provinsi Bali. Jurnal PIRAMIDA, 12(1), 1-12.

Suartha, N., \& Yasa, I. G. W. M. (2017). Pengaruh Pertumbuhan Ekonomi, Migrasi Masuk Terhadap Pertumbuhan Penduduk dan Alih Fungsi Bangunan Penduduk Asli Kota Denpasar. Jurnal Ekonomi Kuantitatif Terapan, 10(1), 95-107.

Wiagustini, N. L. P., Mustanda, I. K., Meydianawathi, L. G., \& Abundanti, N. (2017). Potensi Pengembangan Investasi Berbasis Ekonomi Kreatif di Kota Denpasar. Jurnal Ekonomi Kuantitatif Terapan, 10(2), 1-20. 
Widnyana., I. D. G. A. W., Budhi, M. K. S., \& Saskara, I. A. N. (2017). Penentu Kesejahtraan"Pemindangan"di Kabupeten Tabanan. Jurnal Ekonomi Kuantitatif Terapan, 10(1), 1-20.

Wiyasa., I. B. W., \& Dewi, M. H. U. (2017). Faktor Faktor yang Mempengaruhi Pendapatan Melalui Curahan Jam Kerja Ibu Rumah Tangga Pengerajin Bambu di Kabupaten Bangli. Jurnal PIRAMIDA, 13(1), 1-20. 